STUDIA PRAWNO-EKONOMICZNE, t. CIV, 2017

PL ISSN 0081-6841; e-ISSN 2450-8179 $\quad$ s. 135-158

DOI: 10.26485/SPE/2017/104/8

\title{
Tadeusz SZULC*
}

\section{NIERÓWNOŚĆ STANOWA W MAŁŻEŃSTWACH JAGIELLONÓW I KRÓLÓW ELEKCYJNYCH}

\begin{abstract}
(Streszczenie)
Na dwadzieścia związków małżeńskich zawartych przez monarchów polskich z dynastii Jagiellonów i królów elekcyjnych pięć miało charakter niedynastyczny. Zarzut nierówności stanowej wysunięto wobec czterech małżonek królewskich. W krytyce wyboru małżonek podkreślano wyjątkową pozycję władcy, kontrastującą z niższą stanowo pozycją wybranki. Szczególnie znalazło to wyraz w trakcie sporu o drugie małżeństwo Zygmunta Augusta. Argumentowano, że Zygmunt wywodzi się z dynastii królewskiej, jako król był pomazańcem Bożym. Z tego względu winien był wstąpić w związek tylko z osobą równą mu stanem. Jako osoba publiczna powinien był poddać się wymogom wynikającym z królewskiego majestatu. Monarchowie nie liczyli się jednak z głosami sprzeciwu. Jedynie w przypadku Władysława IV zadbano o zrównanie statusu społecznego jego wybranki z książęcego rodu ze statusem rodziny królewskiej.
\end{abstract}

Słowa kluczowe: małżeństwa niedynastyczne; nierówność stanowa

\section{Wprowadzenie}

Stanisław Ciołek, sekretarz kancelarii królewskiej, na początku XV w. napisał, że żona monarchy nie może być niższa urodzeniem, powinna dorównywać małżonkowi szlachetnościa, postawa, pięknościa, rodem i potęgą ${ }^{1}$. Partnerka powinna

* Dr hab., prof. UŁ, Uniwersytet Łódzki, Wydział Prawa i Administracji, Katedra Badań nad Rozwojem Państwa i Prawa, Zakład Badań nad Rozwojem Ustrojów Państwowych; e-mail: tadeusz_szulc@wp.pl

1 S. Ciołek, Satyra na matżeństwo Władysława Jagietly z Elżbietą Granowska, w: Toć jest dziwne a nowe. Antologia literatury polskiego średniowiecza, oprac. A. Jelicz, PIW, Warszawa 1987, s. 273. Podobny pogląd wyraził Mikołaj Rej: [...] szukajże sobie żonki staniku sobie równego, wychowania a ćwiczenia roztropnego, obyczajów nadobnych a wstydliwych, a pomocy 
pochodzić z tej samej warstwy społecznej. Piszący dwa stulecia później Krzysztof Opaliński w satyrze Na zaloty i malżeństwa nierówne i nieuważne radził:

O równe się ty zawsze staraj ożenienie,

Żeby cię nie potkało takowe odrwienie,

Jakiego się podobno mało co spodziewasz.

$[\ldots]$

Jeśli szlachcic, szlachciankę niech pojmuje, jeśli

Chłop, chłopównę, a jeśli wielkiej familiji,

O takąż się niech stara. [... $]^{2}$.

Preferowano łączenie osób z tych samych stanów społecznych, zasada ta obowiązywała także w rodzinach monarszych ${ }^{3}$.

Od reguły tej zdarzały się odstępstwa, zarówno na dworach Europy Zachodniej, jak i wśród królów polskich ${ }^{4}$. Za przykład posłużyć może związek Katarzyny Medycejskiej z młodszym synem Franciszka I króla Francji, Henrykiem Orleańskim, zawarty w 1533 r. Katarzyna, osierocona po urodzeniu ${ }^{5}$, była księżniczką bez księstwa ${ }^{6}$. Jej przodkowie wywodzili się z rodu kupieckiego, lichwiarskiego ${ }^{7}$,

wzdy jakiej, jaka może być, M. Rej, Żywot człowieka poczciwego, oprac. J. Krzyżanowski, ZN im. Ossolińskich, Wrocław 1956, s. 110.

2 K. Opaliński, Satyry, wyd. L. Eustachiewicz, Zakład im. Ossolińskich Wydawnictwo PAN, Wrocław 1953, s. 48, 50.

3 Przykładem byli Habsburgowie, zob. E. Hubert, A.T. Midro, $W$ mroku genów europejskich rodów panujących, Ananke [biuletyn Galerii im. Śleńdzińskich] 2006/1 (45), Białystok 2006, s. 9-15; I. Kraszewski, Powiązania dynastyczne Piastów wielkopolskich, w: H. Kóčki-Krenz (red.), Przemystowie wielkopolscy od księcia dzielnicowego do króla Polski, Wydawnictwo pokonferencyjne, Konferencja popularnonaukowa towarzysząca Dniom Grodu Przemysła 27 września 2007 r. Muzeum Archeologiczne w Poznaniu, Poznań 2008, s. 62; S. Grodziski, Habsburgowie. Dzieje dynastii, Secesja, Kraków 2013, s. 100-107, 109-110; J. Tegowski, Polska rodzina dynastyczna $w X-X V$ wieku, w: C. Kukla (red.), Rodzina, gospodarstwo domowe i pokrewieństwo na ziemiach polskich $w$ perspektywie historycznej - ciaglość czy zmiany, Wydawnictwo DiG, Warszawa 2013, s. 43; J. Heluszka, Związki dynastyczne książat opolskich w XIV wieku, Annales Universitatis Paedagogicae Cracovienis Studia Historia 2013/XIII, s. 79, 82-83, 85-86, 90-92.

4 Pomijamy nieoficjalne związki monarchów i pochodzące $\mathrm{z}$ nich dzieci nieślubne, zob. T. Szulc, Kochanki i nieprawe dzieci królów polskich w okresie elekcyjnym (w świetle ówczesnych relacji), Studia z Dziejów Państwa i Prawa Polskiego, t. X, red. J. Malec, Krakowskie Towarzystwo Edukacyjne sp. z o.o. - Oficyna Wydawnicza AFM, Kraków 2007, s. 127-145.

5 J. Héritier, Katarzyna Medycejska, PIW, Warszawa 1981, s. 16; N. Goldstone, Królowe rywalki. Katarzyna Medycejska królowa Margot, Prószyński i S-ka, Warszawa 2016, s. 21-22.

6 J. Héritier, op. cit., s. 16; J.F. Solnon, Katarzyna Medycejska. Złowroga królowa Francji, Świat Książki, Warszawa 2007, s. 26; N. Goldstone, op. cit., s. 22.

7 J.F. Solnon, op. cit., s. 29-30. Małżeństwo uchodziło za mezalians; J. Héritier, op. cit., s. 32; B. Craveri, Kochanki i królowe. Władza kobiet, Wydawnictwo W.A.B., Warszawa 2008, s. $17-18$. 
tytuł książęcy uzyskali od Karola $\mathrm{V}^{8}$. Trudno było im się równać z Walezjuszami, boczną gałęzią Kapetyngów.

Podobnie było w dynastii Tudorów za panowania Henryka VIII. Anna Boleyn, druga żona Henryka, ze strony ojca wywodziła się z bogatego kupiectwa londyńskiego, jej pradziad pełnił funkcję burmistrza i wówczas otrzymał szlachectwo9. Matka Anny, Elizabeth, najstarsza córka Thomasa Howarda, drugiego księcia Norfolk, pochodziła z arystokracji ${ }^{10}$. Trzecia z kolei żona, Jane Seymour, była córką sir Johna Seymour, ziemianina z Wolf Hall w Wiltshire ${ }^{11}$, który tytuł szlachecki otrzymał od króla Henryka VII w 1497 r. ${ }^{12}$ Jane była damą dworu dwóch poprzednich żon Henryka VIII, brat jej był dworzaninem ${ }^{13}$. Piąta żona króla, Katarzyna Howard pochodziła z potężnego rodu. Ojciec jej, lord Edmund, był synem drugiego księcia Norfolk ${ }^{14}$, pełnił funkcję komendanta Calais. Matka Jane, Joyce Culpeper, była bratanicą ks. Norfolku ${ }^{15}$. Szóstą żoną monarchy została młoda, dwukrotna wdowa, Katarzyna Parr ${ }^{16}$. Jej ojcem był Thomas lord Kendal, matką Maud Green dama dworu Katarzyny Aragońskiej, córka i dziedziczka sir Thomasa Greena lorda z Greens Norton w Northamptonshire. Ojciec, nobilitowany przez Henryka VIII ${ }^{17}$, pełnił urzędy: szeryfa Northamptonshire, dowódcy straży i rewizora Henryka VIII, był również doradcą królewskim. Wymienione małżonki monarsze pochodziły z zamożnych rodzin, przedstawiciele których pełnili różne urzędy, jednakże nie wywodziły się z rodów panujących.

8 Encyklopedyja Powszechna, t. 18, nakład, druk i własność S. Orgelbrand, Warszawa 1864, s. 290, s.v. Medyceusze; J. Héritier, op. cit., s. 21.

9 D. Starkey, Królowe. Sześć żon Henryka VIII, Dom Wydawniczy Rebis, Poznań 2004, s. 274; zob. A.F. Pollard, Henryk VIII, PIW, Warszawa 1979, s. 125; J.Z. Kędzierski, Dzieje Anglii 1485-1939, t. 1 1485-1830, ZN im. Ossolińskich, Wrocław-Warszawa-Kraków-Gdańsk-Lódź 1986, s. 40.

10 A.F. Pollard, op. cit., s. 125; J.Z. Kędzierski, op. cit., s. 40; A. Fraser, Sześć żon Henryka VIII, Wydawnictwo Rachocki i S-ka, Pruszków 1994, s. 77; D. Starkey, op. cit., s. 275.

11 Przodkowie Seymourów podobnie jak Boleynowie związali się z elitami kupieckimi, A. Fraser, op. cit., s. 154.

12 A. Fraser, op. cit., s. 155.

13 A.F. Pollard, op. cit., s. 220; J.Z. Kędzierski, op. cit., s. 56.

14 D. Starkey, op. cit., s. 649. Ojciec Edmunda został nobilitowany w 1515 r., A. Fraser, op. cit., s. 209.

15 J. Z. Kędzierski, op. cit., s. 70.

16 A.F. Pollard, op. cit., s. 258. Pierwszym mężem jej był Edward Borough szambelan Anny Boleyn, drugim John Neville lord Latimer (dwukrotny wdowiec); A. Fraser, op. cit., s. 240-241.

17 A. Fraser, op. cit., s. 240. 
Podobny charakter miał też związek Kazimierza Wielkiego z Krystyną, zwaną przez Długosza Rokiczaną, zapewne wdową po Mikuláš'u rajcy praskim ${ }^{18}$.

Za Jagiellonów i królów elekcyjnych na dwadzieścia jeden związków małżeńskich, w których pozostawali monarchowie polscy, pięć zostało zawartych w czasie, gdy nic nie wskazywało na to, że małżonek zasiądzie na polskim tronie. $\mathrm{Z}$ tej przyczyny nie uwzględniamy wymienionych poniżej związków w naszych rozważaniach, mianowicie: Aleksandra Jagiellończyka wielkiego księcia litewskiego z Heleną córką Iwana III ${ }^{19}$; Jana Sobieskiego chorążego wielkiego koronnego z Marią Kazimierą Zamoyską d'Arquien wdową po Janie Zamoyskim „Sobiepanie”20; Fryderyka Augusta Wettyna księcia saskiego, syna elektora saskiego Jana Jerzego III z Krystyną Eberhardyną córką margrabiego Chrystiana Ernesta von Brandenburg-Bayreuth ${ }^{21}$; Stanisława Leszczyńskiego syna Rafała Leszczyńskiego podskarbiego w. koronnego, starosty generalnego wielkopolskiego z Katarzyną Opalińską córką Jana Karola Opalińskiego starosty osieckiego i kasztelana poznańskiego oraz Zofii Katarzyny z Czarnkowskich starościanki międzyrzeckiej²2; Augusta Wettyna syna Augusta II Sasa z Marią

18 J. Wyrozumski, Kazimierz Wielki, Ossolineum, Wrocław-Warszawa-Kraków-Gdańsk-Łódź 1982, s. 211; K. Jasiński, Matżeństwa i koligacje polityczne Kazimierza Wielkiego, Studia Źródłoznawcze Commentationes 1990/XXXII/XXXIII, s. 69-70.

19 Data zawarcia małżeństwa 18 lutego 1495 r., PSB, t. IX, s. 360, s.v. Helena (1476-1513) żona Aleksandra Jagiellończyka (autor J. Garbacik); K. Strasz, Aleksander Jagiellończyk w Wilnie i na ziemiach. W. Ks. Litewskiego, nakładem Dziennika Urzędowego Kuratorium Okr. Szk. Wileńskiego, Wilno 1935, s. 4. Elekcja na tron Polski odbyła się 3 października 1501 r., zaś koronacja 12 grudnia 1501 r., L. Godlewski, Ewolucja poglądów Jana Olbrachta i Aleksandra Jagiellończyka w kwestii kształtu unii polsko-litewskiej, Białostockie Teki Historyczne 2016/14, s. 27.

20 Związek został zawarty 5 lipca 1665 r., była to oficjalna data ślubu. Wcześniej jednak, w maju t.r. ze względu na żałobę po pierwszym mężu ordynacie Janie Zamoyskim zawarty został tajny związek małżeński z Janem Sobieskim. Z kolei elekcja nastąpiła 21 maja 1674 r., a koronacja 2 lutego 1676 r., Z. Wójcik, Jan Sobieski 1629-1696, PIW, Warszawa 1983, s. 101-103, 218-219, 249.

21 Ślub nastapił 20 stycznia 1693 r., natomiast elekcja 27 czerwca 1697 r.; koronacja 15 września 1697 r., PSB t. XV, s. 493, s.v. Krystyna Eberhardyna (1670-1727) (autor J. Gierowski); J. Staszewski, August II Mocny, Ossolineum, Wrocław-Warszawa-Kraków 1988, s. 32-33, $60-61$.

22 Ślub został zawarty 3 maja 1696 r., natomiast elekcja nastąiła 12 lipca 1704 r., zaś koronacja 4 października 1704 r., J. Feldman, Stanisław Leszczyński, oprac. i wstęp J. Staszewski, PIW, Warszawa 1984, s. 37, 42, 53, 70; PSB, XII, s. 216, s.v. Katarzyna Opalińska (autor Ryszard W. Wołoszyński); S. Karwowski, Leszczyńscy herbu Wieniawa, W I Związkowej Drukarni we Lwowie, Lwów 1916, s. 34 przypis 3 z odesłaniem: Arch. Leszczyńskich. Rydzyna 1696, w piątek po niedzieli Conductus Paschae; podobnie J. Feldman, op. cit., s. 42-43. Z kolei 
Józefą Habsburg córką Józefa I cesarza rzymskiego i Wilhelminy Amalii hanowerskiej córki księcia brunszwickiego na Lüneburgu Jana Fryderyka Welfa i Benedykty Wittelsbach ${ }^{23}$.

Za małżeństwo niedynastyczne uznajemy związek, w którym partnerka nie wywodzi się z rodziny panującej przynajmniej od dwóch pokoleń.

Celem niniejszego artykułu jest przedstawienie reakcji otoczenia królewskiego na decyzję panującego odnośnie do wyboru partnerki na żonę oraz wpływu otoczenia na postanowienie powzięte przez władcę.

Przedmiotem naszych rozważań są małżeństwa pięciu królów polskich: Władysława II Jagiełły z Elżbietą Granowską, a następnie z Sonką Holszańską, Zygmunta I z Barbarą Zapolyą, Zygmunta Augusta z Barbarą Radziwiłłówną i związek Władysława IV Wazy z Ludwiką Marią Gonzaga (de Nevers). Ten ostatni związek włączyliśmy dlatego, że stało się on dynastycznym w wyniku starań podjętych przez dyplomację polską na żądanie króla Władysława. W negocjacjach poprzedzających zawarcie tego związku małżeńskiego uzgodniono, że przyszła małżonka, wywodzi się... z Królewskiej gatęzi Burbonów, Alencon, Bourgogne i uznano ją za francuską księżniczkę krwi ${ }^{24}$. Starania strony polskiej zostały podjęte w wyniku krytyki, że monarcha bierze za żonę poddaną obcego władcy. Postanowiono, że Ludwika Maria stanie się równą stanowo królowi polskiemu.

Dostępne źródła zawierają materiał, który rozkłada się nierównomiernie na powyżej wymienione niedynastyczne związki matrymonialne. Większą bazą źródłową i literaturą dysponujemy dla związku Zygmunta I i Barbary Zapolyi,

Edmund Cieślak jako datę ślubu podaje rok 1698, bez wskazania źródeł, zob. E. Cieślak, Stanisław Leszczyński, Ossolineum, Wrocław-Warszawa-Kraków 1994, s. 35.

23 Do zawarcia związku doszło 20 sierpnia 1719 r., z kolei elekcja miała miejsce 5 października 1733 r., koronacja 17 stycznia 1733 r. PSB, XXI, s. 1, s.v. Maria Józefa (autor J. Staszewski); J. Staszewski, August III, Ossolineum, Wrocław-Warszawa-Kraków-Gdańsk-Lódź 1989, s. 92; T. Ciesielski, Propagandowy wymiar uroczystości dworskich $w$ pierwszych latach panowania Augusta III, Wieki Stare i Nowe 2015/8(13), s. 49-50.

24 Księżniczka Ludwika Maria non seulement en consideration de Sa Naissance, \& de ses grandes \& rares qualitez; mais à cause de la proche parenté, qui la joint à leurs Majestez, estant issue des branches Royales de Bourbon, d'Alençon, \& de Bourgogne, \& aiant esté ainsi elevée, aupres de la Reine, qui i aime comme sié etoit sa propre Fille [...] zob. M. Dogiel, Codex diplomaticus Regni et Magni Ducatus Lithuaniae, t. 1, cz. 1-2, Vilno 1758, Dok. IX, s. 469. Podobnie w punkcie III kontraktu zamieszczono sformułowanie, że Ludwika Maria jest dla króla francuskiego estant sa proche parente, et née des Princesses du Sang Roial jest bliską krewną, urodzoną z książąt krwi królewskiej, ibidem, s. 470; zob. T. Szulc, Status prawnomajątkowy Ludwiki Marii de Gonzaga w świetle intercyz matżeńskich z roku 1645 i 1649, Studia Prawno-Ekonomiczne 2015/XCVI, s. 150-152. 
Zygmunta II Augusta i Barbary Gasztołdowej Radziwiłłówny oraz Władysława IV Wazy i Ludwiki Marii de Nevers. Podstawę źródłową tego artykułu są przekazy drukowane ${ }^{25}$.

\section{Pochodzenie społeczne małżonek królewskich}

Wybranki królewskie wywodziły się z rodów usytuowanych w górnej warstwie społeczności feudalnej.

Trzecią żoną Jagiełly została Elżbieta z Pilczy 3-o voto Granowska ${ }^{26}$. Ojcem jej był Otto z Pilczy zaufany Kazimierza Wielkiego i królowej Elżbiety Łokietkównej, wojewoda i starosta sandomierski ${ }^{27}$. Był on jednym z najbogatszych i wpływowych panów małopolskich ${ }^{28}$. Matką jej była Jadwiga Melsztyńska, córka Jana z Melsztyna, kasztelana krakowskiego, chrzestna matka Jagiełły ${ }^{29}$.

25 Kroniki, pisma polityczne, prace, pamiętniki, listy: Marcina Bielskiego, Stanisława Ciołka, Codex diplomaticus Regni Poloniae et Magni Ducatus Lithuaniae, t. 1 Macieja Dogiela; Jodoka L. Decjusza, Roczniki Jana Długosza, Michel de Marolles, Françoise B. de Motteville, Stanisława Orzechowskiego, Pamiętniki do panowania Zygmunta III, Władysława IV i Jana Kazimierza $\mathrm{z}$ rękopisu wyd. K.W. Wójcicki; Stanisława A. Radziwilla, Macieja Stryjkowskiego, Bernarda Wapowskiego, Wesele Zygmunta I z Barbara Zapolska, w: M. Wiszniewski, Pomniki historyi i literatury Polskiey..., t. 4; Wypis z podróży Pani de Guebriant, posłowej nadzwyczajnej do Polski, za Władysława IV, w: J.U. Niemcewicz, Zbiór pamiętników historycznych o dawnej Polsce..., t. 4, nakład i wydanie nowe Jana Nepomucena Bobrowicza, Lipsk 1839; Źródła, w: K. Waliszewski, Polsko-francuskie stosunki w XVII wieku. 1644-1667. Opowiadania i źródta historyczne ze zbiorów archiwalnych francuskich publicznych i prywatnych, Druk. UJ, Kraków 1889.

26 Trzeci mąż Elżbiety, Wincenty z Granowa, starosta generalny wielkopolski zmarł w $1410 \mathrm{r}$. Związek z Władysławem Jagiełłą był dla niej czwartym związkiem małżeńskim, Encyklopedyja Powszechna, t. 8, nakład i druk S. Orgelbrand, Warszawa 1861, s. 248, s.v. Elżbieta, Helżbieta, z Pilczy (J. Bartoszewicz); A. Prochaska, Dlugosz o Eli̇biecie trzeciej żonie Jagiełty, nakład redakcji Tygodnika, Lwów 1876, s. 15-16. Do zawarcia związku doszło w 1417 r., w rok po śmierci drugiej żony Władysława Jagiełły Anny Cylijskiej, zob. PSB, t. 1, s. 121 s.v. Anna Cylejska (autor K. Pieradzka); Z. Wdowiszewski, op. cit., s. 67-68.

27 S. Gawęda, Możnowładztwo małopolskie $w$ XIV $i$ w pierwszej połowie XV wieku. Studium $z$ dziejów rozwoju wielkiej własności ziemskiej, ZNUJ CXLI Prace Historyczne z. 18, nakładem UJ, Kraków 1966, s. 48; PSB, t. XXIV, s. 634, s.v. Otto z Pilczy (autor B. Wyrozumska); O.M. Przybyłowicz, Elżbieta Granowska: trzecia żona Władysława Jagiełly. Życie codzienne królowej, Kwartalnik Historii Kultury Materialnej 1997/XLV/1, s. 4.

28 W. Dworzaczek, Leliwici Tarnowscy. Z dziejów możnowładztwa małopolskiego. Wiek XIV-XV, IW PAX, Warszawa 1971, s. 89, 93.

29 PSB, t. XX, s. 413, s.v. Melsztyński Spytek (autor A. Strzelecka); J. Krzyżaniakowa, J. Ochmański, Władysław II Jagietło, Ossolineum, Wrocław-Warszawa-Kraków-Gdańsk - Łódź 1990, s. 91; O.M. Przybyłowicz, op. cit., s. 4. 
Bratem jej był bliski współpracownik Jagiełły, Spytek z Melsztyna, wojewoda krakowski ${ }^{30}$. Pileccy i Melsztyńscy mieli swój udział w wyniesieniu Jagiełły na tron Polski ${ }^{31}$. Elżbieta pochodziła z rodziny zamożnej, zostawszy po raz kolejny wdową, posiadała ogromny majątek. Córka Elżbiety Pileckiej, również Elżbieta, wyszła za Bolka V Opolskiego przed lub w tym samym roku co jej matka za Jagiełłę

Dwa lata po śmierci Elżbiety Granowskiej żoną króla została Zofia (Sonka), córka Andrzeja Iwanowic Holszańskiego, namiestnika kijowskiego z ramienia Witolda $^{33}$. Ojciec Andrzej był bratem Julianny Holszańskiej, żony wielkiego księcia litewskiego Witolda ${ }^{34}$, czyli rodzina była spowinowacona z Giedyminowiczami ${ }^{35}$. Matką Zofii była księżna Aleksandra Dymitrówna Drucka ${ }^{36}$. Ojciec Zofii Andrzej był obecny wraz z bratem Semenem i ich ojcem księciem

30 PSB, t. XX, s. 413-414; W. Dworzaczek, op. cit., s. 120; S.M. Kuczyński, Król Jagietło ok. 1351-1434, Wydawnictwo MON, Warszawa 1985, s. 80.

31 U. Borkowska OSU, Dynastia Jagiellonów w Polsce, Wydawnictwo Naukowe PWN, Warszawa 2011, s. 486.

32 A. Prochaska, Dlugosz o Elżbiecie trzeciej żonie Jagielty, nakładem redakcji Tygodnika Lwów 1876, s. 17, 33; PSB II, s. 282, s.v. Bolestaw (Bolko) V, ksiażę opolski (autor K. Piotrowicz).

33 J. Tęgowski, Przodkowie Zofii Holszańskiej czwartej żony Władysława Jagietly, Genealogia. Studia i Materiały Historyczne, t. 8, red. M. Górny, Wydawnictwo Historyczne, Poznań-Wrocław 1996, s. 28-29; Z. Wdowiszewski, op. cit., s. 75-76.

34 Encyklopedia Powszechna, t. 28, Nakład i druk S. Orgelbranda, Warszawa 1868, s. 679, s.v. Zofija, królowa Sońka (autor J. Bartoszewicz); U. Borkowska OSU, Dynastia Jagiellonów w Polsce, Wydawnictwo Naukowe PWN, Warszawa 2011, s. 489; W. Zawitkowska, Walka polityczno-prawna o następstwo tronu po Władystawie Jagielle w latach 1424-1434, Wydawnictwo Uniwersytetu Rzeszowskiego, Rzeszów 2015, s. 32.

35 L. Korczak, Monarchia i poddani: system władzy w Wielkim Księstwie Litewskim w okresie wczesnojagiellońskim, Tow. Wydawnicze Historia Jagiellonica, Kraków 2008, s. 74; A.B. Zakrzewski, Wielkie Księstwo Litewskie (XVI-XVIII w.). Prawo - ustrój - społeczeństwo, Wydawnictwo Campidoglio, Warszawa 2013, s. 63.

36 Księżna Aleksandra była wnuczką księcia Dymitra Starszego Olgierdowicza, przyrodniego brata Jagiełły, S.M. Kuczyński, Król Jagiełto ok. 1350-1434, Wydawnictwo MON, Warszawa 1985, s. 85; J. Krzyżaniakowa, J. Ochmański, op. cit., s. 271. Zdaniem J. Tęgowskiego informacja ta nie znajduje potwierdzenia w źródłach, J. Tęowski, Przodkowie Zofii Olszańskiej..., s. 30. W momencie zamążpójścia Zofia wraz z siostrami i matką przebywała u brata matki Semena Dymitrowicza Druckiego, który po śmierci jej ojca był ich opiekunem, zob. J. Tęgowski, Pierwsze pokolenie Giedyminowiczów, Wydawnictwo Historyczne, Poznań-Wrocław 1999, s. 128; Z. Wdowiszewski, Genealogia Jagiellonów i..., s. 76; E. Maleczyńska, Rola polityczna królowej Zofii Holszańskiej na tle walki stronnictw w Polsce w latach 1422-1434, nakładem Tow. Nauk. we Lwowie, Lwów 1936, s. 24-25 [Archiwum Tow. Nauk. we Lwowie, Dział II, t. XIX, z. 3]; S.M. Kuczyński, Król Jagiełto..., s. 86. 
Iwanem Holszańskim przy poręczeniu unii wileńsko-radomskiej w $1401 \mathrm{r}^{37}$ Jej dziadem macierzystym był przyrodni brat Jagiełły Dymitr Olgierdowicz Drucki $^{38}$. Starsza siostra Sonki została wydana za mąż za kniazia Iwana Włodzimierzowicza Bielskiego, młodsza Maria została żoną Eliasza, następcy tronu w Mołdawii ${ }^{39}$. Holszańscy byli kniaziami litewskimi, niedynastyczny$\mathrm{mi}^{40}$, wywodzącymi się z potomków dawnych lokalnych władców litewskich, którzy ulegli deklasacji ${ }^{41}$.

Barbara Zapolya, żona Zygmunta I, wywodziła się z magnackiego rodu podległego monarsze węgierskiemu. Ród Zapolyów pod względem zamożności sytuował się na drugim miejscu po rodzinie Korwinów i z racji zajmowanych stanowisk w państwie nadzorował połowę terenu korony węgierskiej, to znaczy Siedmiogród i Górne Węry ${ }^{42}$. Ojcem Barbary był jeden z najpotężniejszych magnatów węgierskich Stefan Zapolya, wojewoda siedmiogrodzki ${ }^{43}$, hrabia spiski $^{44}$, a jej matką druga żona Stefana, Jadwiga, córka Przemysła III, księcia cieszyńskiego z dynastii Piastów i Anny księżniczki mazowieckiej. Stryjecznym bratem Jadwigi cieszyńskiej był Kazimierz II książę cieszyński i głogowski, sprawujący w latach 1497-1504, 1507-1517 z ramienia Władysława Jagiellończyka króla Czech urząd starosty generalnego i namiestnika królewskiego na Śląsku ${ }^{45}$.

37 A. Boniecki, Poczet rodów w Wielkim Księstwie Litewskim w XV i XVI wieku ułożył..., druk J. Bergera, Warszawa 1883, s. 77; J. Tegowski, Pierwsze pokolenie ..., s. 75; K. Rybska-Bąk, Bulla Eugeniusza IV dla królowej Zofii (1434): wokót obecności schizmatyków na dworze pierwszych Jagiellonów, Średniowiecze Polskie i Powszechne 2014/6 (10), s. 257, przyp. 10.

38 J. Tęgowski, Przodkowie Zofii Olszańskiej..., s. 45.

39 J. Tęgowski, Pierwsze pokolenie..., s. 130.

40 L. Korczak, op. cit., s. 65.

${ }^{41}$ J. Suchocki, Formowanie sie $i$ sktad narodu politycznego $w$ Wielkim Księstwie Litewskim późnego średniowiecza, Zapiski Historyczne 1983/XLVIII/1-2, s. 37-38; L. Korczak, op. cit., s. $57-58$.

42 M. Rekettyés, Stosunki polityczne i kulturalne polsko-węierskie za Władysława Jagiellończyka, Signum, Wrocław 1999, s. 101-102.

43 Najwyższa godność na Węgrzech, urzędnika tego wybierał monarcha spośród czterech kandydatów przedstawionych przez Stany. Był on namiestnikiem władcy podczas jego nieobecności i pośrednikiem między nim a stanami, Encyklopedyja Powszechna, t. 20, nakład i druk S. Orgelbranda, Warszawa 1865, s. 269, s.v. Palatyn (autor F.H. Lewestam).

44 PSB, I, s. 293, s.v. Barbara Zapola (autor W. Pociecha); M. Rekettyés, Stosunki polityczne i kulturalne..., s. 102.

45 PSB XII, s. 290, s.v. Kazimierz (Kaźko) II (ok. 1449-1528) książę cieszyński i głogowski (autor F. Kiryk); red. I. Panic, Dzieje Śląska Cieszyńskiego od zarania do czasów współczesnych, t. 2, Śląsk Cieszyński w średniowieczu (do 1528 roku), przy współpracy B. Czechowicza, Wydawnictwo Starostwo Powiatowe, Cieszyn 2010, s. 180, 185. 
Książę pozostawał w bardzo dobrych kontaktach z Zygmuntem Jagiellończykiem, przyszłym królem ${ }^{46}$.

Barbara Radziwiłłówna, żona Zygmunta II Augusta, była wdową po wojewodzie nowogródzkim Stanisławie Gasztołdzie ${ }^{47}$. Ojcem Barbary był Jerzy Radziwiłł kasztelan wileński, hetman wielki litewski w latach 1531-1541 ${ }^{48}$, jej dziadkiem Mikołaj kanclerz Wielkiego Księstwa Litewskiego, wojewoda wileński, jeden z największych dostojników Wielkiego Księstwa Litewskiego ${ }^{49}$. Jerzy Radziwiłł wraz z bratankiem Janem Radziwiłłem i z Olbrachtem Gasztołdem w latach 1530-1540 sprawowali rzeczywiste rządy na Litwie $^{50}$. Przedstawiciele tego rodu zasiadali w radzie hospodarskiej ${ }^{51}$. Matka Barbary była córką wojewody podolskiego Pawła z Dalejowa, również Barbara ${ }^{52}$, brat jej matki Jan Kola, kasztelan halicki był w latach 1529-1539 hetmanem polnym ${ }^{53}$.

46 L. Finkel, Elekcja Zygmunta I. Sprawy dynastii jagiellońskiej i unii polsko-litewskiej, Napoleon V, Oświęcim 2015 (I wyd. AU, Kraków 1910), s. 23; S. Nowogrodzki, Rządy Zygmunta Jagiellończyka na Śląsku i Łużycach (1499-1506), Napoleon V, Oświęcim 2015 (I wyd. nakładem PAU, Kraków 1937), s. 54-55; Z. Wojciechowski, Zygmunt Stary (1506-1548), oprac. i wstęp A. F. Grabski, PIW, Warszawa 1979, s. 82; Dzieje Śląska Cieszyńskiego od zarania..., s. $185-186$.

47 Gasztołd zmarł w 1542 r., po pięciu latach małżeństwa; W. Ziembicki, Barbara Radziwiłłówna w oświetleniu lekarskim, Pamiętnik Szóstego Powszechnego Zjazdu Historyków Polskich w Wilnie 17-20 września 1935 r., t. 1 Referaty, do druku przygotował F. Podhorecki, nakładem Polskiego Towarzystwa Historycznego, Lwów 1935, s. 144; Z. Wdowiszewski, Genealogia Jagiellonów, IW PAX, Warszawa 1968, s. 104.

48 A. Przeździecki, Jagiellonki polskie w XVI wieku. Obraz rodziny i dworu Zygmunta I i Zygmunta Augusta Królów Polskich, t. 1, w drukarni UJ, Kraków 1868, s. 183; Z. Kuchowicz, Barbara Radziwilłówna, Wydawnictwo Łódzkie, Łódź 1976, s. 14.

49 E. Rudzki, Polskie Królowe. Żony Piastów i Jagiellonów, t. 1, Instytut Prasy i Wydawnictw „Novum”, Warszawa 1985, s. 245; S. Górzyński, Rodzina Radziwiłtów i ich tytuły, w: Radziwiłłowie herbu Trąby, Sł. Górzyński, J. Grala, Wł. Piwkowski, V. Urbaniak, T. Zielińska, NDAP AGAD, DiG, Warszawa 1996, s. 45; M. Antoniewicz, Protoplaści książą Radziwiłlów. Dzieje mitu i meandry historiografii, DiG, Warszawa 2011, s. 26, 66.

50 PSB, t. VII, s. 302, s.v. Gasztołd Olbracht h. Awdaniec (autor W. Pociecha); T. Zielińska, Radziwiłlowie herbu Trąby-dzieje rodu, w: Radziwiltowie herbu..., s. 6.

51 M.B. Topolska, Społeczeństwo, kultura w Wielkim Księstwie Litewskim od XV do XVIII wieku, Bogucki Wydawnictwo Naukowe, Poznań-Zielona Góra 2002, s. 49-50; M. Antoniewicz, op. cit., s. 68.

52 A. Dembińska, Zygmunt I. Zarys dziejów wewnętrzno-politycznych w latach 1540-1548, nakładem Poznańskiego Towarzystwa Przyjaciół Nauk, Poznań 1948, s. 287, przyp. 36; PSB, I, s. 294, s.v. Barbara Radziwiłłówna (autor: W. Pociecha); M. Antoniewicz, op. cit., s. 49.

53 PSB XIII, s. 286, s.v. Kola (Koło) Jan z Dalejowa h. Junosza (autor H. Kowalska). 
Maria Ludwika Gonzaga, poddana Ludwika XIV ${ }^{54}$, była księżniczką de Nevers, córką Karola Gonzagi księcia de Nevers i Katarzyny de Lorraine, księżnej Maine. Wywodziła się z młodszej gałęzi rodu Gonzagów, początek której dał Ludwik, trzeci syn Fryderyka II, księcia Mantui, wysłany za młodu w interesach rodu na dwór francuski. Osiedliwszy się w połowie XVI w. we Francji, służył delfinowi, przyszłemu Franciszkowi II ${ }^{55}$, naturalizując się we Francjii ${ }^{56}$. W 1565 r. poprzez małżeństwo z Henriettą de Cleve, księżną Nevers, hrabiną Rethel, ostatnią z rodu Cleve nabył tytuł księcia de Nevers, stając się kuzynem przyszłego króla Henryka $\mathrm{IV}^{57}$. Z małżeństwa urodziło się pięcioro dzieci. Ludwik IV dał początek młodszej, francuskiej, linii rodu Gonzaga, Ludwika Maria należała do jednej z najświetniejszych i najlepiej skoligaconych rodzin arystokratycznych siedemnastowiecznej Francji. Jej bracia wcześnie zmarli. Siostry Marii Ludwiki oddano do klasztoru. Najmłodsza Benedykta została ksienią klasztoru benedyktynek w Avenay ${ }^{58}$. O rok starsza Anna po śmierci ojca w 1637 r. wystąpiła z klasztoru. W 1645 r. wyszła za mąż za księcia Edwarda de Wittelsbach Simmern, syna elektora Fryderyka V palatynatu reńskiego ${ }^{59}$. Ojciec Marii, Karol I książę de Nevers, Rethel, był parem Francji i księciem d'Arches, gubernatorem Szampanii i Brie, od 1631 r. księciem Mantui i Monferrat ${ }^{60}$. Jako córka udzielnego księcia zaczęła

54 F. de Motteville, Anna Austriaczka i jej dwór, wybór i przekład J. Wachlowska, wstęp i przypisy Z. Libiszowska, Czytelnik, Warszawa 1978, s. 94.

55 Ludwik IV Gonzaga, trzeci syn Fryderyka II księcia Mantui i markiza Montferatu, W.S. Magdziarz, Anna Austriaczka, PIW, Warszawa 2013, s. 77; Ducs de Nevers (Barons de Donzy), s. 5 zob.: Ducs de Nevers-terres et seigneurs en Donziais, www.terres-et-seigneurs-en-donziais.fr/ Les-Ducs-de-Nevers pdf

56 M.Ch. Duvernet, Ėtude Historique. Louis de Gonzague Duc de Nevers, Typographie de P. Bègat, Nevers 1870, s. 3

57 Ducs de Nevers (Barons de Donzy)..., s. 4; J.F. Pavliček, Pobyt Giana Gastona de Medici $v$ Čechach, Školitel: prof. Phdr. Tomáš Knoz, PhD, Brno 2013, s. 33 (Filozofická fakulta Masarykov univerzity Historycký ústav, Disertačni práce).

58 Benedykta ksieni d’Avenay zmarła w 1637 r. w Paryżu, R. Toscan, La Merveilleuse histoire des Ducs de Nevers: Marie de Gonzague, princesse de Nevers et reine de Pologne, Éditions de la Revue du Centre, Paris 1930, s. 40, przyp. 1; K. Targosz, Uczony dwór Ludwiki Marii Gonzagi (1646-1667). Z dziejów polsko-francuskich stosunków naukowych, Ossolineum, Wrocław-Warszawa-Kraków-Gdańsk 1975, s. 13, 24.

59 Historie genealogique et chronologique e la Maison Royale de France, des pairs, grands officiers de la Couronne et de la Maison du Roy... par le P. Anselme, A. Dèchauffè; continée par M. Du Fourny, Tome troisieme, Par la Compagnie des Libraires, a Paris M.DCC.XXVIII, s.713; E. Gillois, Chronique du Nivernois. Les Comtes et les Ducs de Nevers par..., A. Lacroix, Verboeckhoven et c-e, editeurs, Paris 1867, s. 212; R. Toscan, op. cit., s. 40.

60 Starsza linia Gonzagów wymarła w 1626 r. Wojna o sukcesję zakończyła się w 1631 r. Anselme de Saint-Marie, Honore Caille du Fourny, Louis Potier de Courcy, Histoire généalogique et 
się tytułować od roku 1627 Marią Mantuańską ${ }^{61}$ Po śmierci ojca w 1637 r., księstwa Mantui i Montferrat przeszły na jego wnuka, a jej bratanka, Karola III (ur. 31 X 1629 r.) ${ }^{62}$. Francuskie posiadłości Gonzagów, wraz z tytułem księżnej de Nevers, przejęła Maria, uzyskując decyzją królewską dyplom na namiestnictwo tej prowincji ${ }^{63}$. Otrzymała w posiadanie pałac Nevers w Paryżu, zachowała również tytuł księżniczki mantuańskiej.

\section{Reakcja otoczenia na nierówność stanową wybranki}

Wybór małżonki królewskiej ważny był zarówno dla rodziny królewskiej, jak i dworu i szlacheckich poddanych. Małżeństwom dynastycznym, obok celu, jakim było zapewnienie następcy tronu, przyświecały cele polityczne w postaci zawarcia przymierza z sąsiednimi monarchami. Związek małżeński sprzyjał nawiązaniu kontaktów z rodziną panująca, aby pozyskać ją dla realizowanych planów politycznych względnie zneutralizować ${ }^{64}$. Pytanie, kto u boku króla zaj-

chronologique de la Maison Royale de France, des Pairs, Grand Officiers de la Couronne..., t. 3, par la Compaigne des Libraires, a Paris 1728, s. 713; Paul L. Simplicen, L'Etat de la France, Tome troisieme, chez Michel-Etienne David, Paris 1736, s. 59; J.A. Gierowski, Historia Włoch, Ossolineum, Wrocław-Warszawa-Kraków 2003, s. 240.

${ }^{61}$ K. Waliszewski. Maria Mantuańska Królowa Polska 1644-1648. Studium biograficzne na podstawie źródet rękopiśmiennych, Biblioteka Warszawska 1885, t. 3, s. 331, przyp. 3; tenże, Polsko-francuskie stosunki w XVII wieku. Opowiadania i źródta historyczne ze zbiorów archiwalnych francuskich publicznych i prywatnych, Druk. UJ, Kraków 1889, s. 19, przyp. 2; E. Rudzki, Polskie Królowe..., s. 121.

62 Ostatni potomek starszej linii Gonzagów Wincenty II zmarł bezpotomnie w 1627 r. Karol I (linia młodsza, francuska) zeswatał wówczas swego syna Karola II z bratanicą zmarłego, Marią Gonzagą. Ze związku tego pochodzi Karol III, który przejął władzę w 1637 r., R. Toscan, op. cit., s. 36-37.

${ }_{63}$ Pamiętnikarz, opat Michel de Marolles, zanotował: Nostre Princesse obtint du Roi son breuet pour le gouuernement du Niuernois, don't elle s'enalla bien tost après prendre possession [...], M. Marolles de, Les Memoires ... abbé deVilleivin divisez en trios parties ..., chez Antoine de Sommaville, a Paris 1656, s. 120; Le grand Conde et le duc D Engihien, Lettres inédites à Marie-Louise de Gonzague, reine de Pologne, sur la cour de Louis XIV (1660-1667) publiées le manuscript orginal autographe de Chantilli par Emil Magne, ed. Emil-Paul Freres, Paris 1920, s. VI-VII; Encyklopedya Powszechna, t. 18, s.v. Maryja Ludwika Gonzaga de Nevers (autor J. Bartoszewicz), s. 100; PSB, t. XVIII, red. E. Rostworowski, Warszawa-Kraków-Gdańsk 1973, s. 107, s.v. Ludwika Maria Gonzaga (1611-1667), [autor Z. Libiszowska], E. Rudzki, Polskie królowe..., II, s. 124; J.A. Gierowski, Historia Włoch, s. 241.

${ }^{64}$ J. Heluszka, op. cit., s. 82-83, 86; J. Tęgowski, Polska rodzina dynastyczna ..., s. 52-53; R. Smišek, M. Konrádowa, Habsburgowie i Michat Korybut Wiśniowiecki: przyjazd arcyksiężniczki Eleonory Marii do Rzeczypospolitej w 1670 roku jako sposób komunikacji symbolicznej, Historia Slavorum Occidentis 2015/2 (9), s. 101-103. 
mie miejsce małżonki, przyciagało uwagę dworów sąsiednich, jak i otoczenia samego władcy. Strony zainteresowane liczyły na polityczne korzyści, z kolei stronnictwo dworskie za poparcie określonej kandydatki oczekiwało przychylności ze strony tejże w dostępie do różnych form łaski królewskiej. Niebłahą sprawą były zaszczyty otrzymywane od dynastii, z której wywodziła się panna młoda. Te oczekiwania upadały w przypadku małżeństwa niedynastycznego.

W związku z powyższym krytyka otoczenia monarchy koncentrowała się głównie na niskim pochodzeniu stanowym.

Wiadomość o decyzji zawarcia związku małżeńskiego Jagiełly z Elżbieta Granowską odnotowana została we współczesnym wydarzeniom źródle - Satyrze na matżeństwo Władysława Jagiełty z Elżbieta Granowska autorstwa Stanisława Ciołka, sekretarza kancelarii królewskiej ${ }^{65}$, i w późniejszych o prawie pół wieku Rocznikach Jana Długosza ${ }^{66}$. Obaj pisarze podkreślają niższość stanową małżonki króla.

Utwór S. Ciołka ma formę bajki, w której bohaterami są zwierzęta, pod postaciami których kryły się prawdziwe osoby i wydarzenia ${ }^{67}$. Jagiełło przyrównany został do króla zwierząt, lwa. Autor podkreślił, że władca w społecznej hierarchii zajmuje najwyższą pozycję ${ }^{68}$. W związek małżeński mógł wstąpić tylko z osobą równą mu stanem. Kandydatka na żonę powinna była dorównać monarsze szlachetnościa, postawa, pięknościa, rodem i potęga. W sytuacji [...] gdyby ożeniono go [króla] z jego poddana, [...] nie tylko upodlitby się wspaniaty majestat, ale $i$ całe potomstwo nosiłoby piętno zbyt różniących się od siebie rodziców. Owocem nierównego stanem stadła byłyby potwory, albo odrzucajac kształty jednego rodziców - istoty do nich niepodobne [...]. Potomek taki nie będąc podobnym do ojca [...] niegodny jest przejać ojcowska spuściznę i być poważanym ..., kto nie przejąt sity i obyczajów ojcowskich, tym samym nie byłby uprawniony do objęcia tronu. Ciołek podkreśla, że małżeństwo niżej stojącej kobiety [...] z god-

65 T. Tyc, Z dziejów kultury w Polsce średniowiecznej, I Stanisław Ciołek (1382-1437), Fiszer i Majewski, Poznań 1927, s. 35-41; Z. Kowalska, Stanisław Ciołek († 1437) Podkanclerzy królewski, biskup poznański, poeta dworski, Universitas, Kraków 1993, s. 134 i n.; polskie tłumaczenie tekstu: S. Ciołek, Satyra na małżeństwo Władysława Jagielty z Elżbieta Granowska, w: Toć jest dziwne a nowe. Antologia literatury polskiej średniowiecza, oprac. A. Jelicz, PIW, Warszawa 1987, s. 272-276. Satyra została napisana w latach 1417-1419.

66 J. Wyrozumski, 55 lat pracy nad krytyczna reedycja dziejów Polski Jana Dlugosza, Nauka 2006/2, s. 157. Satyra S. Ciołka była znana Długoszowi, Jana Długosza Roczniki czyli Kroniki..., s. 137.

67 T. Tyc, op. cit., s. 36, 38.

68 To szczep najczcigodniejszy, ksiąze dostojny i władca nasz, lew, najpotężniejszy ze zwierząt, S. Ciołek, op. cit., s. 273. 
niejszymi mężami nie prowadzi do równości stanowej tejże kobiety ${ }^{69}$. Cierpiał na tym autorytet władcy ${ }^{70}$. Granowska nie spełniała wymagań, jakie stawiano kandydatce na żonę króla.

Przeciwieństwem wybranki królewskiej, nazwanej w paszkwilu cuchnaca maciora wyjałowiona wieloma pologami, niezdolna już do rodzenia, bo strawiła się w poprzednich zwiazkach, był opis kandydatki na żonę będącej przedstawicielką obcej dynastii ${ }^{71}$.

Zamiar poślubienia Elżbiety spotkał się ze sprzeciwem rady królewskiej ${ }^{72}$, nie pochwalał jej, zdaniem Długosza, książę Witold ${ }^{73}$. Mimo sprzeciwów i perswazji niemal wszystkich prałatów i panów Królestwa Polskiego, szczególnie [...] wojewody poznańskiego Sędziwoja Ostroroga monarcha postawił na swoim, Elżbieta została jego żoną, a następnie była koronowana ${ }^{74}$.

Czwartym małżeństwem Jagiełły był związek zawarty z Sonką Holszańską. Sonka pochodziła z kniaziów litewskich niedynastycznego pochodzenia, tym niemniej była poddanką króla polskiego i wielkiego księcia litewskiego ${ }^{75}$. Decyzja małżeństwa z Sonką spotkała się z krytyką ze strony rady królewskiej z uwagi na brak korzyści politycznych wynikających z zawarcia takiego związku. Kronikarz

69 S. Ciołek, Satyra ..., s. 273. Opinię o nierównym i nieprzyzwoitym matżeństwie króla powtórzyli: Jan Długosz, Roczniki czyli Kroniki..., s. 72, 73; B. Wapowski, Dzieje Korony Polskiej i Wielkiego Księstwa Litewskiego..., s. 392; za nimi M. Bielski, Kroniki..., t. 1 (Księga I, II, III), wydanie Kazimierza Józefa Turowskiego, nakład i druk Karola Pollaka, Sanok 1856, s. 564.

70 Nie wstyd mu [królowi] byto, że przez ten upragniony z ta kobieta zwiąek ostabił osiagająca mnóstwo pomyślnych wyników władzę królewska i że smutnymi namiętnościami doprowadzit do jej załamania się. Im bowiem większym uznaniem cieszyt się król, tym szpetniejszy byt dla niego tego rodzaju związek, który i u obcych, i u swoich podważyt stawę króla zob. Jana Długosza Roczniki czyli Kroniki..., 72; podobnie S. Ciołek, Satyra na matżeństwo Władysława..., s. 273-274.

71 S. Ciołek, Satyra..., s. 274-275.

72 Jana Dlugosza Roczniki czyli Kroniki..., s. 73.

73 Poglądowi Długosza zdaje się zaprzeczać S. Ciołek, zob. Satyra..., s. 276.

74 Jana Długosza Roczniki czyli Kroniki..., s. 76-77. Za Długoszem Bernard Wapowski powtórzył, że: Sędziwój z Ostroroga z wielu innymi panami żwawo opierat się, aby niegodna takiego stopnia, koronowana być miała, B. Wapowski, Dzieje Korony Polskiej i Wielkiego Księstwa Litewskiego..., s. 392; zob. Rozbiór krytyczny Annalium Poloniae Jana Dlugosz z lat 1385-1444, t. 1, oprac. S. Gawęda, K. Sieradzka, J. Radziszewska, K. Stachowska pod kierunkiem J. Dąbrowskiego, Ossolineum, Wrocław-Warszawa-Kraków 1961, s. 171.

75 J. Tęgowski, Przodkowie Zofii Holszańskiej..., s. 28-32; M. Koczerska, Królowa Zofia Olszańska - jej osobowość i rola polityczna, w: W. Zawitkowska (red.), Kobiety o kobietach. Studia i szkice. Średniowiecze i czasy nowożytne, Wydawnictwo UR, Rzeszów 2010, s. 79; B. Czwojdrak, Zofia Holszańska. Studium o dworze i roli królowej w późnośredniowiecznej Polsce, Wydawnictwo DiG, Warszawa 2012, s. 16-17. 
stwierdzał, że były to zaślubiny między nierównymi partnerami: zgrzybiałym już królem Władysławem i młodziutka wówczas wspomniana Zofia $[\ldots]^{76}$. Obiekcje kronikarza okazały się chybione, ze związku tego Jagiełło uzyskał tak długo wyczekiwane potomstwo.

Małżeństwo Zygmunta I z Barbarą Zapolyą spotkało się z niejednakową oceną współczesnych. Jodok L. Decjusz, sekretarz króla Zygmunta I, zanotował Nie brakowało ludzi, którzy wynosili pod niebiosy przygotowywanie tego malżeństwa i radzili je zawrzeć, gdyz miało być szczęśliwe w przyszłości. Ale byli i tacy, co ten projekt potepiali, jako zły i szkodliwy ${ }^{77}$. Zróżnicowaną opinię ówczesnych Polaków i Węrów o wyborze Barbary Zapolyi przez Zygmunta I znajdujemy również w Kronice Marcina Bielskiego. Przeciwnicy związku wytykali nierówne pochodzenie rodu Zapolyów, inni natomiast podkreślali jego cnotę i sławę Barbara Zapolya została żoną Zygmunta I.

Wieść o potajemnym poślubieniu przez Zygmunta Augusta Barbary Radziwiłłównej wywołała wzburzenie opinii szlacheckiej. Podobnie rada wielkoksiążęca w Wilnie w kwietniu 1548 r. nie zaaprobowała wyboru młodego króla ${ }^{79}$, królowa Bona także nie mogła się pogodzić z tym, że Gasztołdowa będzie jej synową ${ }^{80}$.

Szlachta traktowała ślub zawarty potajemnie, bez zasięgnięcia opinii senatu za szkodliwy ${ }^{81}$. Liczne wystąpienia skierowane przeciw małżeństwu królewskiemu miały miejsce na pierwszym, zwołanym po śmierci Zygmunta I Starego, sejmie

76 Jana Długosza Roczniki czyli Kroniki..., s. 166.

77 J.L. Decjusz, Księga o czasach króla Zygmunta, przekład zespoł. Koła Naukowego Studentów Filologii Klasycznej pod kier. K. Kumanieckiego, wstęp i przypisy T. Bieńkowski, PIW, Warszawa 1960, s. 55-56.

78 Kronika polska Marcina Bielskiego, t. 2 (księga IV-V), wydanie Kazimierza Józefa Turowskiego, nakład i druk Karola Pollaka, Sanok 1856, s. 962; za nim G. Lengnich, Prawo pospolite Królestwa Polskiego..., t. 1, w Drukarni Stanisława Stachowicza, Kraków 1761, s. 525. Zdaniem Mariana Dubieckiego negatywne nastawienie szlachty węgierskiej wywołane było zawiścią, zob. M. Dubiecki, Przedstawicielki dawnych dynasty. Zarys historyczny, w: idem, Obrazy i studya historyczne, Serya II, nakład Gebethnera i Wolffa, Warszawa 1899, s. 205-206.

79 [...] khdy to ustyszali i dowiedali pewnosty, Panowie rada Welikoho Kniażestwa, iż Korol $z$ toju Paniejeu potajemnie szlub brat, i serdecznie toho żałowali, i poczali upominaty i prosity Korola slezno aby toho ne czynit i nierowny sobie, Poddanoje swojeje za matżonku nie brat potom wsim ludiem, $i$ wsiej ziemli, toje ożenienie Korolewskoje byto welmi niemiło, a mnogie tomu wiery dopustity niechotieli, i mnogie paszkwili pisali o tom [...], T. Narbutt, Pomniki do Dziejów Litewskich pod względem historycznym, dyplomatycznym, geograficznym itp. ... zebrane przez ..., nakładem Rubena Rafałowicza Księgarza Wileńskiego, Wilno 1846, s. 79-80.

80 S. Cynarski, Zygmunt August, Ossolineum, Wrocław-Warszawa-Kraków 2004, s. 52.

81 M. Ferenc, Mikołaj Radziwiłt „Rudy” (ok. 1515-1584). Działalność polityczna i wojskowa, Tow. Wyd. „Historia Jagiellonica”, Kraków 2008, s. 94. 
koronnym w Piotrkowie 1548 r. Stanisław Orzechowski pisze, że zdaniem posłów żona nie była królowi równa [...] że białogłowa lubo prawda wysoko urodzona $i$ wielkiego pokrewieństwa w Litwie, będąc jednak podległa królowi, równego wspaniałości królewskiej przynieść nie mogła pokrewieństwa ${ }^{82}$. Urodzenie możnowładcze nie było równe stanowi królewskiemu. Jako przykład równego stanowo związku małżeńskiego Marcin Zborowski, kasztelan kaliski, podał małżeństwo Aleksandra Jagiellończyka z Heleną, córką Iwana III. Aleksander był wielkim księciem litewskim, jego żona córką wielkiego księcia moskiewskiego ${ }^{83}$. Posłowie szlacheccy zwracali uwagę na fakt, że Zygmunt August jako monarcha zajmuje szczególne miejsce w hierarchii organów państwowych. Jest osobą publiczną, w związku z czym nie jest sprawą obojętną dla posłów, kto zostanie jego małżonką. Piotr Boratyński argumentował, że malżeństwo [...] między nierównymi, to jest między panem i poddana, między pomazańcem bożym a wdowa, nie poszło $z B o g a^{84}$. Dostojeństwo godności monarszej, według współczesnych, wykluczało małżeństwo z osobą niższego stanu. Monarcha przez namaszczenie został wyniesiony ponad ogół. W jego osobie przenikał się byt boski z pierwiastkiem ludzkim, z tego względu nie przystoi mu wchodzić w związek z osobą niższego stanu.

Starosta generalny wielkopolski Andrzej Górka w imieniu całej rady królewskiej i stanu szlacheckiego, powołując się na prawo zwyczajowe, stwierdzał: iście to matżeństwo WKMci z poddana złaczone teraz nie ma: a iż się też za tem matżeństwem powiada o przyochędożeniu nizkiego stanu tej tam matżonki WKMci wysokim stanem królewskim, toć każdy najj. Miłościwy Królu przyznawać musi, iżeś WKM. zacnościa swa okrasić raczyt tej to paniej, aleś WKM [...] stan osoby swej królewskiej, tudzież poddanych swych niepomatu poniżyć raczyt, pojąwszy WKM. poddana $[\ldots]^{85}$. A. Górka wyraził pogląd, że poddana przez małżeństwo z monarchą nie pozbywa się dawnej przynależności stanowej. Na zawarciu takiego związku korzysta tylko ród, z którego pochodzi królewska wybranka ${ }^{86}$. Dodatkową przeszkodą był fakt niedawnego przyjęcia przez jej ród wiary chrze-

82 Kroniki Stanisława Orzechowskiego, thum. z łacińskiego M.Z.A. Włyński, wyd. K.J. Turowski, nakład i druk Karola Pollaka, Sanok 1856, s. 26-27.

83 [...] bytoż też za króla Aleksandra, iż będac Panem w Litwie pojąt sobie moskiewkę stanu sobie równego, bo książęcego, a sam też byt Księciem wielkim tylko, [...], Dyaryusz sejmu piotrkowskiego 1548, w: Dyaryusze sejmów koronnych 1548, 1553 i 1570 z rkp. wyd. J. Szujski, nakładem Komisyi historycznej Towarzystwa naukowego krakowskiego, Kraków 1872, s. 215.

84 Cyt. za L. Górnicki, Dzieje w Koronie Polskiej, oprac. H. Barycz, Ossolineum, Wrocław 2003, s. 27 , zob. s. $26,28,29$.

85 Dyaryusz sejmu piotrkowskiego 1548, s. 204.

${ }_{86}$ Zob. wypowiedź P. Boratyńskiego, Dyaryusz sejmu piotrkowskiego 1548, s. 203-204. 
ścijańskiej i wejścia w szeregi szlachty ${ }^{87}$. W odpowiedzi monarcha oznajmił, że prawo wyboru małżonki przysługuje każdemu, nawet osobom najmniejszych stanó $^{88}$, w związku z tym [...] chce téz JKM, będac i Królem i Panem tejże wolności i swobody użyć w obieraniu żony sobie ${ }^{89}$. Mówcy szlacheccy byli innego zdania. Dowodzili, że wolność wyboru służy miłościwy Królu między tylko sobie równymi conditia $[\ldots]^{90}$, Barbara nie spełniała tego warunku.

Monarcha swoim postępowaniem ma być wzorem dla poddanych. Wojewoda łęczycki Mikołaj Jarunt, mówiąc o małżeństwie Zygmunta II Augusta, uzasadniał: [...] persona Regis non est privata sed publica, przeto jako stawny jest uczynek pański ku uciesze i slawie poddanym, tak też i grzech i obładzenie i zły uczynek królewski nie może być jeno z upadkiem a osława pospólstwa9 ${ }^{9}$. Podobnie Ossoliński w trzecim wystapieniu mówił najj. mitościwy Królu gdy kto publicam personam gerit, ten stan nie tylko czynienia ku zelżywości albo ku szkodzie onym, podle których i wezwania i przełożenia dostat, jako jest od Polaków Król polski wezwan, czynić nie może, ale ani żadnych innych nie wedle stanu swego rzeczy, aczby też nie owszem szkodliwych używać mu nie przysto ${ }^{92}$. Mówcy podkreślali, że monarchę jako osobę publiczną obowiązują zasady przynależne jego stanowi, których musi przestrzegać. Podobnej argumentacji użył P. Boratyński, wskazywał na odmienność stanową króla. Składały się na nią: urodzenie w dynastii królewskiej, sakra królewska ${ }^{93}$. Władca nie może podejmować decyzji, które uwłaczają jego królewskiemu majestatowi, jak również tym, którzy wynieśli go na tron. Wykluczone, aby kierował się nakazem serca, winien uwzględniać przede wszystkim interes monarchii, interes poddanych. Zygmunt August odrzucił

87 Dyaryusz sejmu piotrkowskiego 1548..., s. 204; chrystianizację Litwy rozpoczęto w r. 1386. Gasztołdowie, jako ród bojarski wyznania rzymskokatolickiego postanowieniem unii horodelskiej, zostali przyjęci do polskiego rodu herbowego Abdank.

89 Ibidem, s. 177-178.

90 Trzecie wystąienie Piotra Boratyńskiego, ibidem, s. 204, Albowiem jako jest rzecz honestis moribus przeciwna, gdy ktoz szlachetnego albo rycerskiego stanu będac, pojmie nierzkać kmiotówne poddana swa, ale i stawetnego miasta mieszczkę, acz nikogo postronnego tem ani zelży ani uszkodzi, jeno sam siebie [...].

91 Dyaryusz sejmu piotrkowskiego 1548..., s. 198.

92 Ibidem, s. 204.

93 Racz wasza krolewska miłość sam na się okiem rozumu wejrzeć, jeśli stanowi waszej królewskiej miłości, wysokiemu urodzeniu, krolowi pomazanemu którym nasza jest ostatnia nadzieja, takie ożenienie przystoi? Nie tego czekała korona nie ten owoc uróść miał z dobrego przyrodzenia waszej królewskiej miłości, nie ten z dobrego wychowania, IV Mowa Piotra Boratyńskiego [...], w: Wybór mów staropolskich świeckich sejmowych i innych, zebrał A. Małecki..., wyd. K.J. Turowski, nakładem Wydawnictwa Biblioteki Polskiej, Kraków 1860, s. 17. 
żądanie unieważnienia związku, powołując się na nierozerwalność małżeńskiego sakramentu ${ }^{94}$.

Sprawa pochodzenia wybranki królewskiej za Wazów wyniknęła w trakcie obrad senatu w 1635 r. Na posiedzeniu Władysław IV, wystapił z wnioskiem o rozważenie ożenku monarchy z Polką, nie podając kogo miał na myśli. Zdania senatorów były podzielone. [O]bawiano się żeby ten honor zpowinowacenia się z Krulem Adwersarzowi iego nie dostat się, a przez kolligacia żeby w gurę Krul niewynios ${ }^{95}$. Zwolennicy monarchy, przywołując małżeństwa Jagiełły z Granowską i Holszańską, jak i Zygmunta II Augusta z Radziwiłłówną, argumentowali, że Rzeczypospolita z tego tytułu nie poniosła żadnej szkody. Władysław IV w $1637 \mathrm{r}$. pojął za żonę Cecylię Renatę Habsburg.

Po jej śmierci król powziął zamiar zawarcia małżeństwa z Marią Ludwiką de Nevers, poddaną króla Francji, odrzuciwszy inne kandydatki, co spotkało się z krytyką ${ }^{96}$. Kwestia ożenku z Marią Ludwiką była przedmiotem rokowań pomiędzy posłem francuskim Nicolasem de Flécelles hrabią de Brégy a kanclerzem wielkim koronnym Jerzym Ossolińskim ${ }^{97}$. Na wniosek Władysława IV, strona polska ze względu na powagę polskiego monarchy żądała, aby Francja oficjalnie traktowała Ludwikę Marię jako równą francuskim księżniczkom $\mathrm{krwi}^{98}$. Postanowienie to zamieszczono w układzie prowizorycznym, podpisanym 17 lipca 1645 r. w Warszawie ${ }^{99}$. Uzgodniono, że małżeństwo Władysława IV z Ludwiką Marią jest równe znaczeniem mariażowi z francuską księżniczką krwi. Postanowienie powyższe znalazło potwierdzenie w intercyzie małżeńskiej zawartej 26 września 1645 r. w Fontainebleau ${ }^{100}$. W pamiętniku Albrecht Stanisław Radziwiłł, kanclerz wielki litewski, odnotował, że Ludwi-

94 Zob. wypowiedzi Zygmunta Augusta, Dyaryusz sejmu piotrkowskiego 1548..., s. 177-178, 182-183.

95 Pamiętniki do panowania Zygmunta III, Władysława IV i Jana Kazimierza z rękopisu wyd. K.W. Wójcicki, t. 1, Wydawnictwo Orgelbrand S., Warszawa 1846, s. 237.

96 M. Serwański, Francja wobec Polski..., s. 343.

97 L. Kubala, Jerzy Ossoliński, t. I, nakładem Księgarni Gubrynowicza i Schmidta, Lwów 1883, s. 250,308 ,

98 W. Czapliński, Władysław IV wobec wojny 30-letniej (1637-1645), nakładem PAU, Kraków 1937, s. 110; M. Serwański, Francja wobec Polski..., s. 343-344.

99 XX. Point consentis entre le sieur Brégy de Flécelles et le Sénateurs de Polotne pour le mariaże de la Princesce; Warszawa 17 lipca pkt 1, w: K. Waliszewski, Polsko-francuskie stosunki w XVII wieku. 1644-1667. Opowiadania i źródła historyczne ze zbiorów archiwalnych francuskich publicznych i prywatnych, Drukarnia UJ, Kraków 1889, s. 201.

${ }^{100}$ Pacta matrimonialia Inter Vladislaum IV. Regem Poloniae ac Ludovicam Mariam Gonzagam, Ludovici XIV Regis Galitae, w: M. Dogiel, Codex diplomaticus Regni Poloniae et Magni Ducatus Lithuaniae, t. I, cz. 1-2, Vilno 1758, s. 469-473. 
ka Maria przed zamażpójściem została dekretem ogłoszona córka Królestwa Francji $i^{101}$. Aktem tym wprowadzono Ludwikę Marię do rodziny królewskiej. Uznanie Ludwiki Marii za królewską córę Francji sytuowało ją wysoko w hierarchii społecznej. Tytuł Madame de France przysługiwał tylko córce króla. W wyniku negocjacji status społeczny Ludwiki Marii uległ zmianie, jako że stała się członkiem dynastii panującej, co sprawiło, że małżeństwo jej z królem Polski przestało być niedynastyczne. Był to wyjątek.

\section{Wnioski}

Na ogół na żonę władcy wybierano osobę z dynastii panującej. Na szesnaście związków małżeńskich zawartych przez monarchów polskich $\mathrm{z}$ dynastii Jagiellonów i królów elekcyjnych pięć miało charakter niedynastyczny. Zarzut nierówności stanowej małżonek królewskich został postawiony w stosunku do czterech kandydatek na żonę. Mianowicie wobec Elżbiety Granowskiej, Barbary Zapolyi, Barbary Gasztołdowej i Marii Ludwiki de Nevers. Wyjątkiem była Sonka Olszańska. Trzy z pięciu wybranek królów polskich były ich poddanymi, dwie poddanymi obcych monarchów, którzy na zawarcie przez nie związku małżeńskiego z obcym władcą wyrazili zgodę.

W wypowiedziach krytykujących wybór małżonki podkreślano wyjątkową pozycję władcy, kontrastującą z niższą stanowo pozycją rodu wybranki. Dysproporcja ta najbardziej uwidoczniona została w trakcie sporu o małżeństwo Zygmunta Augusta. Mówcy kładli nacisk na fakt, że Zygmunt wywodzi się z dynastii królewskiej, jako król był pomazańcem Bożym, czyli osobą wyniesioną ponad ogół świecki. $Z$ tego względu winien był wstapić w związek tylko z osobą równą mu stanem. Jako osoba publiczna w kwestii zawarcia związku małżeńskiego powinien był uwzględniać ograniczenia wynikające z królewskiego majestatu. Monarchowie nie liczyli się jednak z głosami sprzeciwu wobec niestanowego pochodzenia wybranki. Wyjątek stanowił Władysław IV, na żądanie którego aby uciszyć głosy krytyczne, zadbano o zrównanie statusu społecznego jego wybranki ze statusem rodziny królewskiej.

${ }^{101}$ A.S. Radziwill, Pamiętnik o dziejach $w$ Polsce, t. 2: 1637-1646, przekł. i oprac. A. Przyboś, R. Żelewski, PIW, Warszawa 1980, s. 456. Z. Wdowiszewski odsyła do S.A. Radziwill, Pamiętniki, wyd. E. Raczyński, U braci Scherów, Poznań 1839, s. 175. 


\section{Bibliografia}

Antoniewicz Marceli, Protoplaści książąt Radziwiłtów. Dzieje mitu i meandry historiografii, DiG, Warszawa 2011.

Bielski Marcin, Kronika Polska ..., ks. V, W drukarni A. Gałęzowskiego i komp. ..., Warszawa 1830, w: Zbiór Pisarzow Polskich, cz. 5, t. XVI.

Bielski Marcin, Kroniki..., t. 1 (Księga I, II, III), wydanie Kazimierza Józefa Turowskiego, nakład i druk Karola Pollaka, Sanok 1856.

Boniecki Adam, Poczet rodów w Wielkim Księstwie Litewskim w XV i XVI wieku ułożyt..., druk J. Bergera, Warszawa 1883.

Borkowska Urszula OSU, „, Pacta Matrymonialia” Domu Jagiellonów, Roczniki Humanistyczne 2000, Zeszyt Specjalny Historia t. XLVIII - z. 2 - Cursus mille annorum ofiarowane Profesorowi Eugeniuszowi Wiśniowskiemu, s. 44-60.

Borkowska Urszula OSU, Dynastia Jagiellonów w Polsce, Wydawnictwo Naukowe PWN, Warszawa 2011.

Chronique du Nivernois. Les Comtes et les Ducs de Nevers par E. Gillois, A. Lacroix Verboeckhoven et c-e, editeurs, Paris 1867.

Cieślak Edward, Stanisław Leszczyński, Ossolineum, Wrocław-Warszawa-Kraków 1994.

Codex Epistolaris Vitoldi Magni Ducis Lithuaniae 1376-1430, ed. A. Prochaska, Wydawnictwo Komisyi Historycznej AU w Krakowie nr 23, Kraków 1882.

Cravieri Benedetta, Kochanki i królowe. Władza kobiet, Wydawnictwo WAB, Warszawa 2008.

Cynarski Stanisław, Zygmunt August, Ossolineum, Wrocław-Warszawa-Kraków 2004.

Czapliński Władysław, Władysław IV wobec wojny 30-letniej (1637-1645), nakładem PAU, Kraków 1937.

Czwojdrak Bożena, Zofia Holszańska. Studium o dworze i roli królowej w późnośredniowiecznej Polsce, Wydawnictwo DiG, Warszawa 2012.

Decjusz Jodok L., Księga o czasach króla Zygmunta, przekład zespoł. Koła Naukowego Studentów Filologii Klasycznej pod kier. K. Kumanieckiego, wstęp i przypisy T. Bieńkowski, PIW, Warszawa 1960.

Dembińska Anna, Zygmunt I. Zarys dziejów wewnętrzno-politycznych w latach 1540-1548, Poznań: nakładem Poznańskiego Towarzystwa Przyjaciół Nauk 1948.

Dyaryusze sejmów koronnych 1548, 1553 i 1570 z rkp. wyd. J. Szujski, nakładem Komisyi historycznej Towarzystwa naukowego krakowskiego, Kraków 1872 [SRP, I].

Długosza Jana Roczniki czyli Kroniki Stawnego Królestwa Polskiego, księga jedenasta 1413-1430, red. i komentarz S. Gawęda, PWN, Warszawa 1985.

Dogiel Maciej, Codex diplomaticus Regni et Magni Ducatus Lithuaniae, t. 1, cz. 1-2, Vilno 1758.

Dubiecki Marian, Przedstawicielki dawnych dynasty. Zarys historyczny, w: idem, Obrazy i studya historyczne, Serya II, nakład Gebethnera i Wolffa, Warszawa 1899.

Ducs de Nevers (Barons de Donzy), s. 5 zob.: Ducs de Nevers-terres et seigneurs en Donziais, www.terres-et-seigneurs-en-donziais.fr/Les-Ducs-de-Nevers pdf

Duvernet M. Ch., Etude Historique. Louis de Gonzague Duc de Nevers, Typographie de P. Bègat, Nevers 1870.

Dworzaczek Włodzimierz, Leliwici Tarnowscy. Z dziejów możnowładztwa małopolskiego. Wiek $X I V-X V$, IW PAX, Warszawa 1971. 
Panic Idzi (red.), Dzieje Śląska Cieszyńskiego od zarania do czasów współczesnych. Tom 2. Śląsk Cieszyński w średniowieczu (do 1528 roku), współpr. Bogusław Czechowicz, Starostwo Powiatowe, Cieszyn 2010.

Encyklopedyja Powszechna, t. 2-28, nakład i druk S. Orgelbranda, Warszawa 1860-1868.

Feldman Józef, Stanisław Leszczyński, oprac. i wstęp Jacek Staszewski, PIW, Warszawa 1984.

Ferenc Marek, Mikołaj Radziwiłt „Rudy” (ok. 1515-1584). Działalność polityczna i wojskowa, Tow. Wyd. „Historia Jagiellonica”, Kraków 2008.

Finkel Ludwik, Elekcja Zygmunta I. Sprawy dynastii jagiellońskiej i unii polsko-litewskiej, Napoleon V, Oświęcim 2015 (I wyd. AU, Kraków 1910).

Fraser Antonia, Sześć żon Henryka VIII, Wydawnictwo Rachocki i S-ka, Pruszków 1994.

Gawęda Stanisław, Możnowładztwo małopolskie w XIV $i$ w pierwszej połowie XV wieku. Studium z dziejów rozwoju wielkiej własności ziemskiej, ZNUJ CXLI Prace Historyczne, z. 18, nakładem UJ, Kraków 1966.

Gierowski Józef A., Historia Włoch, Ossolineum, Wrocław-Warszawa-Kraków 2003.

Godlewski Lukasz, Ewolucja pogladów Jana Olbrachta i Aleksandra Jagiellończyka w kwestii ksztattu unii polsko-litewskiej, Białostockie Teki Historyczne 2016/14, s. 23-40.

Goldstone Nancy, Królowe rywalki. Katarzyna Medycejska królowa Margot, Prószyński i S-ka, Warszawa 2016.

Grodziski Stanisław, Habsburgowie. Dzieje dynastii, Secesja, Kraków 2013.

Górnicki Lukasz, Dzieje w Koronie Polskiej, oprac. Henryk Barycz, Ossolineum, Wrocław 2003.

Górzyński Slawomir, Rodzina Radziwitłów i ich tytuty, w: Radziwiłlowie herbu Trąby, Sławomir Górzyński, Jolanta Grala, Włodzimierz. Piwkowski, Violetta Urbaniak, Teresa Zielińska, NDAP AGAD, DiG, Warszawa 1996.

Graff Tomasz, Zbigniew Oleśnicki (1423-1455) wobec husytyzmu i polityki polsko-czeskiej, Mediaevalia Historia Bohemia 17/1, Praha Historycký ústav 2014, s. 128-167.

Heluszka Joanna, Związi dynastyczne książąt opolskich w XIV wieku, Annales Universitatis Paedagogicae Cracovienis Studia Historia XIII (2013), s. 78-92.

Héritier Jean, Katarzyna Medycejska, PIW, Warszawa 1981.

Historie genealogique et chronologique e la Maison Royale de France, des pairs, grands officiers de la Couronne et de la Maison du Roy... par Perè Anselme, Augustyn Dèchauffè; continée par Honore Du Fourny, ... Tome troisieme, Par la Compagnie des Libraires, a Paris M.DCC.XXVIII.

Hubert Ewa, Midro Alina T., $W$ mroku genów europejskich rodów panujących, Ananke [biuletyn Galerii im. Śleńdzińskich] 2006/1 (45), Białystok 2006.

Jasiński Kazimierz, Malżeństwa i koligacje polityczne Kazimierza Wielkiego, Studia Źródłoznawcze Commentationes 1990/XXXII/XXXIII, s. 67-76.

Kantecki Klemens P., Elżbieta trzecia żona Jagietly. Opowiadanie historyczne, Nadbitka z Przeglądu Naukowego i Literackiego, nakładem Księgarni Gubrynowicza i Schmidta, Lwów 1874.

Kędzierski Jerzy Z., Dzieje Anglii 1485-1939, t. 1 1485-1830, ZN im. Ossolińskich, Wrocław Lettres inédites-Warszawa-Kraków-Gdańsk-Lódź 1986.

Koczerska Maria, Królowa Zofia Olszańska - jej osobowość i rola polityczna, w: Wioletta Zawitkowska (red.), Kobiety o kobietach. Studia i szkice. Średniowiecze i czasy nowożytne, Wydawnictwo UR, Rzeszów 2010, s. 76-95.

Korczak Lidia, Monarchia i poddani: system władzy w Wielkim Księstwie Litewskim w okresie wczesnojagiellońskim, Tow. Wydawnicze Historia Jagiellonica, Kraków 2008. 
Kowalska Zofia, Stanisław Ciołek $(\uparrow$ 1437) Podkanclerzy królewski, biskup poznański, poeta dworski, Universitas, Kraków 1993.

Kraszewski Igor, Powiąania dynastyczne Piastów wielkopolskich, w: Hanna Kóčki-Krenz (red.), Przemystowie wielkopolscy od księcia dzielnicowego do króla Polski, Wydawnictwo Pokonferencyjne. Konferencja popularnonaukowa towarzysząca Dniom Grodu Przemysła 27 września 2007 roku Muzeum Archeologiczne w Poznaniu, Poznań 2008, s. 55-64

Krzyżaniakowa Jadwiga, Ochmański Jerzy, Władysław II Jagiełto, Ossolineum, Wrocław -Warszawa-Kraków-Gdańsk-Lódź 1990.

Kubala Ludwik, Jerzy Ossoliński, t. 1, nakładem Księgarni Gubrynowicza i Schmidta, Lwów 1883.

Kuchowicz Zbigniew, Barbara Radziwiłtówna, Wydawnictwo Łódzkie, Łódź 1976.

Kuczyński Stanisław Maria, Król Jagiełto ok. 1350-1434, Wydawnictwo MON, Warszawa 1985.

Lengnich Gottfried, Prawo pospolite Królestwa Polskiego..., t. 1, Drukarnia Stanisława Stachowicza, Kraków 1761.

Magdziarz Wojciech S., Anna Austriaczka, PIW, Warszawa 2013.

Magne Emil, Le grand Conde et le duc D'Engihien. Lettres inédites à Marie-Louise de Gonzague, reine de Pologne, sur la cour de Louis XIV (1660-1667) publiées d'après le manuscrit original autographe de Chantilly par ..., ed. Emil-Paul Freres, Paris 1920.

Maleczyńska Ewa, Rola polityczna królowej Zofii Holszańskiej na tle walki stronnictw w Polsce w latach 1422-1434, nakładem Tow. Nauk. we Lwowie, Lwów 1936.

Marolles Michel de, Les Memoires ... abbé de Villeivin divisez en trios parties ..., chez Antoine de Sommaville, a Paris 1656.

Motteville Françoise de, Anna Austriaczka i jej dwór, wybór i przekład Irena Wachlowska, wstęp i przypisy Zofia Libiszowska, Czytelnik, Warszawa 1978.

Narbutt Teodor, Pomniki do Dziejów Litewskich pod względem historycznym, dyplomatycznym, geograficznym itp. ... zebrane przez ..., nakładem Rubena Rafałowicza Księgarza Wileńskiego, Wilno 1846.

Niemcewicz Julian U., Zbiór pamiętników historycznych o dawnej Polsce..., t. 4, nakład i wydanie nowe Jana Nepomucena Bobrowicza, Lipsk 1839.

Nitkiewicz Maria R., Królowa Elżbieta z Pilczy i Łańcuta, trzecia żona Władysława Jagietly, Muzeum - Zamek w Łańcucie, Łańcut 2003.

Nowogrodzki Stanisław, Rządy Zygmunta Jagiellończyka na Śląsku i Łużycach (1499-1506), Napoleon V, Oświęcim 2015 (I wyd. nakładem PAU), Kraków 1937).

Opaliński Krzysztof, Satyry, wyd. L. Eustachiewicz, Zakład im. Ossolińskich Wydawnictwo PAN, Wrocław 1953

Orzechowski Stanisław, Kroniki..., tłum. z łacińskiego M.Z.Al. Włyński, wyd. K. J. Turowski, nakład i druk Karola Pollaka, Sanok 1856.

Polski Słownik Biograficzny, t. I, II, VI.

Pamiętniki do panowania Zygmunta III, Władysława IV i Jana Kazimierza z rkps wydał K.Wł. Wójcicki, nakład i druk S. Orgelbranda, Warszawa 1846.

Pavliček Jan F., Pobyt Giana Gaszona de Medici v Čechach, Školitel: prof. Phdr. Tomáš Knoz, PhD, Brno 2013, (Filozofická fakulta Masarykov univerzity Historycký ústav, Disertačni práce).

Pollard Albert F., Henryk VIII, PIW, Warszawa 1979. 
Prochaska Antoni, Dlugosz o Elżbiecie trzeciej żonie Jagiełly, nakładem redakcji Tygodnika, Lwów 1876.

Przeździecki Aleksander, Jagiellonki polskie w XVI wieku. Obraz rodziny $i$ dworu Zygmunta I i Zygmunta Augusta królów polskich, t. 1, w drukarni UJ, Kraków 1868.

Przybyłowicz Olga M., Elżbieta Granowska: trzecia żona Władysława Jagiełty. Życie codzienne królowej, Kwartalnik Historii Kultury Materialnej 1997/XLV/1, s. 3-15.

Przybyszewski Bolesław Ks., Barbara Zapolya Królowa Polski 1512-1515, De Arte, Łańcut 2000 .

Radziwill Albrycht S., Pamiętniki, wyd. E. Raczyński, U braci Scherów, Poznań 1839.

Radziwill Albrycht S., Pamiętniki o dziejach w Polsce, t. 2, 1637-1646, przekł. i oprac. Adam Przyboś, Roman Żelewski, PIW, Warszawa 1980.

Rej Mikołaj, Żywot człowieka poczciwego, oprac. Julian Krzyżanowski, ZN im. Ossolińskich, Wrocław 1956

Rekettyés Maria, Stosunki polityczne i kulturalne polsko-wegierskie za Władysława Jagiellończyka, Signum, Wrocław 1999.

Rozbiór krytyczny Annalium Poloniae Jana Dlugosz z lat 1385-1444, t. 1, oprac. Stanisław Gawęda, Krystyna Sieradzka, Julia Radziszewska, Krystyna Stachowska pod kierunkiem Jana Dąbrowskiego, Ossolineum, Wrocław-Warszawa-Kraków 1961.

Rudzki Edward, Polskie Królowe. Żony Piastów i Jagiellonów, t. 1, Instytut Prasy i Wydawnictw „Novum”, Warszawa 1985.

Rybska-Bąk Karolina, Bulla Eugeniusza IV dla królowej Zofii (1434): wokół obecności schizmatyków na dworze pierwszych Jagiellonów, Średniowiecze Polskie i Powszechne 2014/6 (10), s. $255-269$.

Serwański Michal, Francja wobec Polski $w$ dobie wojny trzydziestoletniej (1618-1648), Wydawnictwo Naukowe UAM, Poznań 1986.

Saint-Marie Anselme de, Caille du Fourny Honore, Potier de Courcy Louis, Histoire généalogique et chronologique de la Maison Royale de France, des Pairs, Grand Officiers de la Couronne..., t. 3, par la Compaigne des Libraires, a Paris 1728.

Simplicen Paul L., L'Etat de la France, Tome troisieme, chez Michel-Etienne David, Paris 1736.

Smišek Rostislav, Konrádowá Monika, Habsburgowie i Michat Korybut Wiśniowiecki: przyjazd arcyksiężniczki Eleonory Marii do Rzeczypospolitej w 1670 roku jako sposób komunikacji symbolicznej, Historia Slavorum Occidentis 2015/2 (9), s. 101-136.

Solnon Jean-François, Katarzyna Medycejska. Złowroga królowa Francji, Świat Książki, Warszawa 2007.

Starkey David, Królowe. Sześć żon Henryka VIII, Dom Wydawniczy Rebis, Poznań 2004.

Staszewski Jacek, August III, Ossolineum, Wrocław-Warszawa-Kraków-Gdańsk-Lódź 1989.

Strasz Kazimierz, Aleksander Jagiellończyk w Wilnie i na ziemiach. W. Ks. Litewskiego, nakładem Dziennika Urzędowego Kuratorium Okr. Szk. Wileńskiego, Wilno 1933.

Sucheni-Grabowska Anna, Zygmunt August Król Polski i Wielki Książę Litewski 1520-1563, Wydawnictwo Krupski i S-ka, Warszawa 1996.

Suchocki Jerzy, Formowanie się i skład narodu politycznego w Wielkim Księstwie Litewskim późnego średniowiecza, Zapiski Historyczne 1983/XLVIII/1-2, s. 31-73.

Szulc Tadeusz, Kochanki i nieprawe dzieci królów polskich w okresie elekcyjnym ( w świetle ówczesnych relacji), w: Jerzy Malec (red.), Studia z Dziejów Państwa i Prawa Polskiego, t. X, Krakowskie Towarzystwo Edukacyjne sp. z o.o. - Oficyna Wydawnicza AFM, Kraków 2007, s. $127-145$. 
Szulc Tadeusz, Status prawnomajątkowy Ludwiki Marii de Gonzaga w świetle intercyz malżeńskich z roku 1645 i 1649, Studia Prawno Ekonomiczne, ŁTN, 2015/XCVI, s. 145-162.

Targosz Karolina, Uczony dwór Ludwiki Marii Gonzagi (1646-1667). Z dziejów polsko-francuskich stosunków naukowych, Ossolineum, Wrocław-Warszawa-Kraków-Gdańsk 1975.

Tęgowski Jan, Przodkowie Zofii Holszańskiej czwartej żony Władysława Jagietly, Genealogia. Studia i Materiały Historyczne, t. 8, red. M. Górny, Wydawnictwo Historyczne, Poznań -Wrocław 1996, s. 27-45.

Tęgowski Jan, Pierwsze pokolenie Giedyminowiczów, Wydawnictwo Historyczne, Poznań-Wrocław 1999.

Tęgowski Jan, Polska rodzina dynastyczna w X-XV wieku, w: Cezary Kukla (red.), Rodzina, gospodarstwo domowe i pokrewieństwo na ziemiach polskich $w$ perspektywie historycznej - ciagłość czy zmiany, Wydawnictwo DiG, Warszawa 2013, s. 31-54.

Toć jest dziwne a nowe. Antologia literatury polskiej średniowiecza, oprac. Antonina Jelicz, PIW, Warszawa 1987.

Topolska Maria B., Społeczeństwo, kultura w Wielkim Księstwie Litewskim od XV do XVIII wieku, Bogucki Wydawnictwo Naukowe, Poznań-Zielona Góra 2002.

Toscan Raoul, La Merveilleuse histoire des Ducs de Nevers : Marie de Gonzague, princesse de Nevers et reine de Pologne, Éditions de la Revue du Centre, Paris 1930.

Tyc Teodor, Z dziejów kultury w Polsce Średniowiecznej : Stanisława Ciołek(1382-1437), Fiszer i Majewski, Poznań 1927.

Waliszewski Kazimierz, Polsko-francuskie stosunki w XVII wieku. 1644-1667. Opowiadania $i$ źródła historyczne ze zbiorów archiwalnych francuskich publicznych i prywatnych, Druk. UJ, Kraków 1889.

Waliszewski Kazimierz, Maria Mantuańska Królowa Polska 1644-1648. Studium biograficzne na podstawie źródet rękopiśmiennych, Biblioteka Warszawska 1885, t. 3, s. 321-342.

Wapowski Bernard, Dzieje Korony Polskiej i Wielkiego Księstwa Litewskiego od roku 1380 do 1535 przez..., wyd. M. Malinowski, t. 1, nakładem i czcionką Teofila Glückberga, Wilno 1847.

Wdowiszewski Zygmunt, Genealogia Jagiellonów, IW PAX, Warszawa 1968.

Wdowiszewski Zygmunt, Genealogia Jagiellonów i Domu Wazów w Polsce, Avalon, Kraków 2005.

Wiszniewski Michal, Pomniki historyi i literatury Polskiey..., t. 4, wyd. w Drukarni D.E. Friedleina, Kraków 1837.

Wojciechowski Zygmunt, Zygmunt Stary (1506-1548), PIW, Warszawa 1979.

Wyrozumski Jerzy, Kazimierz Wielki, Ossolineum, Wrocław-Warszawa-Kraków-Gdańsk -Łódź 1982.

Wybór mów staropolskich świeckich sejmowych i innych, zebrał A. Małecki..., wyd. K.J. Turowski, nakładem Wydawnictwa Biblioteki Polskiej, Kraków 1860.

Wyrozumski Jerzy, 55 lat pracy nad krytycznq reedycja dziejów Polski Jana Długosza, Nauka 2006/2, s. 153-166.

Zawitkowska Wioletta, Walka polityczno-prawna o następstwo tronu po Władysławie Jagielle w latach 1424-1434, Wydawnictwo Uniwersytetu Rzeszowskiego, Rzeszów 2015,

Ziembicki Witold, Barbara Radziwiłłówna w oświetleniu lekarskim, Pamiętnik Szóstego Powszechnego Zjazdu Historyków Polskich w Wilnie 17-20 września 1935 r., t. 1, Referaty, do druku przygotował F. Podhorecki, nakładem Pols. Tow. Histor., Lwów 1935, s. 144-162. 
Tadeusz SZULC

\section{ESTATES INEQUALITIES OF THE JAGIELLONIANS AND ELECTION KINGS MARRIAGES}

( Summary)

Out of the twenty marriages of the Polish monarchs since the Jagiellonian dynasty five had nondynastic character. In four cases the claims of the inappropriate state status of the royal spouse were raised. Critics of the choice of the king's wife underlined the unique position of the monarch contrasting with the lower state status of the bride. Especially king Zygmunt August's second marriage was highly disputed during a long-lasting debate where the above mentioned arguments were raised. It was argued that king Zygmunt was a descendent of the old royal dynasty and his power came from God. For this reason, he should have married only a woman equal to him. As public person, he should have obeyed the requirements of his royal majesty. Monarchs, however, did not respect the opinion of the opposition. Only in case of the marriage of Wladyslaw IV the efforts were made to ensure the equality of the social status of his wife of duchy family with the status of royal family.

Keywords: non-dynastic marriages; inappropriate state status 